\title{
Synthesis and characterization of 4-[(E)-(-2,5- dimethoxybenzylidene)amino] benzoic acid Schiff base and evaluation as corrosion inhibitor of steel in $2.0 \mathrm{M} \mathrm{H}_{2} \mathrm{SO}_{4}$.
}

\section{${ }^{* 1}$ ECHEM OGBONDA G; OFORKA, NC; JAMES ABOSEDE}

\author{
Department of Science Laboratory Technology, Rivers State Polytechnic, Bori. \\ ${ }^{2 \& 3}$ Department of pure and industrial chemistry university of Port Harcourt \\ PMB 5023; Port Harcourt River State
}

\begin{abstract}
KEYWORDS: Schiff base, corrosion, chemisorption, weight loss and gasometric technique
ABSTRACT: The synthesis of 4-[(E)-(-2,5- dimethoxybenzylidene)amino] benzoic acid Schiff base, SBDAB was carried out inorder to determine its inhibitory efficiency at higher temperature using weight loss and gasometric techniques. The results showed that the inhibition efficiency of the studied Schiff base increased with increase in temperature for the corrosion of mild steel which suggests chemisorption reaction mechanism. The negative free energy of adsorption obtained confirms a spontaneous adsorption of the Schiff base on the metal surface. The positive values of the heat of adsorption suggest an endothermic reaction. The positive values of the entropy of adsorption suggest a disordered system. The Langmuir adsorption Isotherm result showed a deviation from an ideal Langmuir adsorption isotherm equation, this is due to the interaction of the inhibitor molecules with one another. The inhibition efficiency of $35.20 \%$ and $35.31 \%$ was obtained for the weight loss and gasometric techniques respectively. The plots of $\log ($ wi $-\Delta w)$ against time gave linear graph which confirms a first order reaction mechanism. (JASEM
\end{abstract}

\section{http://dx.doi.org/10.4314/jasem.v18i1.9}

Introduction: Compounds containing an azomethine group $(-\mathrm{C}=\mathrm{N}-)$ are known as Schiff bases; (Jones, 2000, Mohammed, 2011). They are usually formed by condensation of a primary amine with a carbonyl compounds according to the following reaction:

$\mathrm{R}-\mathrm{NH}_{2}+\mathrm{R}-\mathrm{COH} \rightarrow \mathrm{R}-\mathrm{N}=\mathrm{CH}-\mathrm{R}+\mathrm{H}_{2} \mathrm{O}$ where $\mathrm{R}$ may be an aromatic or aliphatic group.

Schiff bases of aliphatic aldehyde are relatively unstable and are readily polymerizable while those of aromatic aldehydes, having an effective conjugation system, and are more stable. The chain on the nitrogen makes the Schiff base a stable imine, Jezowska, et al., (1988).

According to Zumdahl (1986), metals corrode because they oxidize easily. With the exception of gold, those metals commonly used for structural and decorative purposes all have standard reduction potentials less positive than that of oxygen gas. The UV- Vis spectra of Schiff base depend on the transition of unpaired electrons from the ground state to the excited state. Some of acceptable absorption band suggesting the presence of $\mathrm{n} \rightarrow \mathrm{n} *$ transition are 242nm (El-hassy, 2004); 237nm, 270nm, and 335nm (Mounika et al., 2010).

Pavia et al., (2001) gave the range of $\mathrm{v}(\mathrm{C}=\mathrm{N})$ absorption band of free azomethine to be between $1650-1550 \mathrm{~cm}^{-1}$. The investigation of the IR absorption band for substituent groups such as $\mathrm{v}(\mathrm{C}=\mathrm{N})$ and aromatic carbons were reported as $1430 \mathrm{~cm}^{-1}-1514 \mathrm{~cm}^{-1}$ and $3068 \mathrm{~cm}^{-1}-3218 \mathrm{~cm}^{-1}$ respectively by Singh et al., (1994) and Bukhari (2002).

Mild steel and their alloys are extensively used in construction, automobile, food industries; unwanted scale such as rust formed in mild steel are removed by immersing the metal in hydrochloric or sulphuric acid solution, this process is known as an acid pickling bath. After the scale is removed, the metal may be subject to attack by the acid, hence in order to reduce the degree of the metal attack, and the rate of consumption of the acid, corrosion inhibitors that are soluble in the acid used for pickling are added to the pickling solution.

Cotton et al., (1987) have reported that nitrogen ligands such as Schiff bases are important in coordination chemistry because of the particular affinity they show toward transition metals.

Ahamad et al., (2009) as cited in Erma (2010) research study stated that the efficiency of Schiff base inhibitor may depend on the nature of the environment, nature of metal surface, electrochemical potential at the interface, and the structural feature of the inhibitor, which includes number of adsorption centers in the molecule, their charge density, the molecular size, and mode of adsorption, formation of metallic complexes and the projected area of inhibitor 
on the metal surface. The aim of this study is to synthesize4-[(E)-(-2,-5 imethoxybenzylidene)amino] benzoic acid Schiff base, study its efficiency in inhibiting steel corrosion at higher temperature in acidic media ( $2 \mathrm{M} \mathrm{H}_{2} \mathrm{SO}_{4}$ ) by weight loss and gasometric methods.

\section{MATERIALS AND METHODS}

Preparation of 4-[(E)-(-2,5-

dimethoxybenzylidene)amino] benzoic acid Schiff base. $4.2127 \mathrm{~g} \quad(0.025 \mathrm{~mol})$ of 3,4dimethoxybenzaldehyde was weighed and dissolved in $80 \mathrm{ml}$ of benzene; into the solution was added $3.4730 \mathrm{~g}(0.025 \mathrm{~mol})$ of 4 -aminobenzoic acid. The mixture was heated at a temperature of $60^{\circ} \mathrm{C}$ in a reflux apparatus until no water appeared. The residue was recrystallized from ethyl acetate $(40 \mathrm{ml})$, an orange solid crystal was obtained and allowed to dry under room temperature. The compound was found to be soluble in DMSO and $\mathrm{H}_{2} \mathrm{SO}_{4}$.

Scheme 1: Synthesis of 4-[(E)-(-2,-5

dimethoxybenzylidene)amino] benzoic acid Schiff base (SBDAB)

Measurement of corrosion rate: The corrosion rate of steel in $2.0 \mathrm{M} \mathrm{H}_{2} \mathrm{SO}_{4}$ was measured by weight loss and gasometric methods ( Mohammed, 2011; Chitra et al., 2010).<smiles>Nc1ccc(C(=O)O)cc1</smiles>

Weight loss method: Preparation of Metal Coupon: Mild steel of $0.1 \mathrm{~cm}$ thickness used for the study was cut into $4 \mathrm{~cm}$ by $5 \mathrm{~cm}$ coupon size for weight loss measurement. The coupons were polished using sandpaper and a hole of $2 \mathrm{~mm}$ was opened at one edge of each coupon. A rubber thread of $25 \mathrm{~cm}$ was passed through the opened hole of each coupon. The coupons were soaked in ethanol solution for 10 minutes for de-greasing, rinsed with distill water, dried in acetone, then heated to constant weight and finally kept in a desicator containing calcium chloride. This is necessary to prevent contamination before usage for corrosion studies. The procedure adopted for this experiment was in accordance with ASTM standard procedure described in the literature (ASTM, 1990, Sethi et al., 2007).

The coupons were added to $0.01 \mathrm{M}, 0.001 \mathrm{M}$, $0.0001 \mathrm{M}, 0.00001 \mathrm{M}$ and $0.000001 \mathrm{M}$ concentrations of the inhibitor in acid media. The corrosion rate is calculated using the following equations:

Corrosion rate $\mathrm{mmp} / \mathrm{year})=$ $87.6 \Delta 7$

Density $x$ Area $x$ Time

$\left(\mathrm{g} / \mathrm{cm}^{3}\right)\left(\mathrm{cm}^{2}\right)(\mathrm{hr})$

Where $\Delta \mathrm{w}=$ weight loss, 87.6 is constant.

Corrosion rate $\left(\mathrm{mg} / \mathrm{dm}^{2} /\right.$ day $)=$ $\Delta \mathrm{w}(\mathrm{mg}) \times 0.001$

Area $/ 100 x$ day

Gasometric method: The corrosion inhibition experiment involving six mild steel coupons $(4 \mathrm{~cm}$ x $5 \mathrm{~cm} \times 0.1 \mathrm{~cm})$ in $2.0 \mathrm{M} \mathrm{H}_{2} \mathrm{SO}_{4}$ acid solutions with the inhibition additives were carried out. The two faces of each of the mild steel metal coupons had $40.0 \mathrm{~cm}^{2}$ total surface area and the weight ranges from $10.1186 \mathrm{~g}-14.3905 \mathrm{~g}$.

The volume of the test solutions used in each experiment was $50 \mathrm{ml}$. A $50 \mathrm{ml}$ of each test solution was introduced into the reaction vessel connected to a burette through a delivery tube. The initial volume of air in the burette was recorded. One metal coupon was dropped into the test solution and the reaction vessel quickly closed. The various possible outlets where the expected hydrogen gas from the reaction cell would likely escape were properly sealed with a masking tape. The volume of hydrogen gas evolved was recorded every 1 minute for 30 minutes for $\mathrm{Al}$ in 2.0 $\mathrm{M} \mathrm{H}_{2} \mathrm{SO}_{4}$ test solutions. Each experiment was conducted on a fresh specimen of metal coupon. The hydrogen gas evolved displaced the fluid in the gasometric set - up, which was read directly.

The experiment was repeated in the presence of the five different concentrations of $1.0 \times 10^{-2} \mathrm{M}$ to $1.0 \mathrm{x}$ $10^{-6} \mathrm{M}$ of the studied Schiff base; as used in the weight loss experiment with the same corrodent concentrations of $2.0 \mathrm{M} \mathrm{H}_{2} \mathrm{SO}_{4}$ solutions.

\section{RESULTS AND DISCUSSIONS}

Identification of the prepared Schiff base: The IR result showed a signal at $1603(\mathrm{C}=\mathrm{N})$ and 1697 ( $\mathrm{COOH}$ ) functional groups, Pavia et al., (2001). The UV-Vis electronic spectral data for the compound gave $\lambda_{\max } 235$ ( $\pi \rightarrow \pi *$ ), Mounika et al., (2010). The melting point was $63-64^{\circ} \mathrm{C}$. This agrees with the result of Echem, et al; (2013). 
Corrosion study: The inhibition efficiency is calculated using the equations below:

$\%$ Inhibition Efficiency $=$

$\frac{\Delta W_{B}-\Delta W_{i}}{\Delta W_{B}} X \frac{100}{1}$

Where $\Delta \mathrm{w}_{\mathrm{B}}$ and $\Delta \mathrm{w}_{\mathrm{i}}$ are weight losses without and with inhibitor respectively.

Table 1: Inhibitor Efficiency with inhibitor concentration $(\mathrm{M})$ for the corrosion of mild steel coupons in $2.0 \mathrm{M} \mathrm{H}_{2} \mathrm{SO}_{4}$ solution containing SBDAB

at different temperatures.

\begin{tabular}{llcc}
\hline $\begin{array}{l}\text { Concentration } \\
(\mathbf{M})\end{array}$ & \multicolumn{3}{c}{$\begin{array}{c}\text { Inhibition Efficiency } \\
(\boldsymbol{\%})\end{array}$} \\
\cline { 2 - 4 } & $\mathbf{3 0 3 K}$ & $\mathbf{3 1 3 K}$ & $\mathbf{3 2 3 K}$ \\
\hline 0.000001 & 8.63 & 18.65 & 24.94 \\
0.00001 & 19.30 & 25.47 & 27.67 \\
0.0001 & 20.73 & 30.30 & 31.71 \\
0.001 & 32.92 & 35.64 & 38.62 \\
0.01 & 35.20 & 37.81 & 39.67 \\
\hline
\end{tabular}

The inhibition efficiency of this Schiff base increases with increase in concentration (Table 1 and Figure 3). This can be attributed to the blocking of active sites of the metal surface, Toliwal et al; (2010). With increase temperature $(303 \mathrm{~K}-313 \mathrm{~K})$ a significant increase in inhibition efficiency was observed, this might be due to the presence of reactive functional groups, high electron density of the donor atom which do not decompose easily at higher temperature; but appears to reduce at a higher temperature of $323 \mathrm{~K}$ probably as a result of decomposition of hydrophobic long chain (Sastri, 1998).

Table 2: Free energy of adsorption $\Delta$ Gads with temperature at different concentrations for SBDAB the inhibition of mild steel corrosion in $2.0 \mathrm{M} \mathrm{H}_{2} \mathrm{SO}_{4}$ solution.

\begin{tabular}{lccc}
\hline \multirow{2}{*}{$\begin{array}{c}\text { Concentration } \\
\text { M) }\end{array}$} & \multicolumn{3}{c}{ Free energy of adsorption $\Delta \mathbf{G a d s}$} \\
\cline { 2 - 4 } $\mathbf{3 0 3 K}$ & $\mathbf{3 1 3 K}$ & $\mathbf{3 2 3 K}$ \\
\hline 0.000001 & -38.62 & -41.54 & -43.40 \\
0.00001 & -34.48 & -36.13 & -37.41 \\
0.0001 & -28.80 & -30.41 & -31.47 \\
0.001 & -23.76 & -24.61 & -25.48 \\
0.01 & 35.20 & 35.31 & \\
\hline
\end{tabular}

\begin{tabular}{llll}
0.01 & -18.02 & -18.68 & -19.32 \\
Average & -28.74 & -30.27 & -31.42 \\
\hline
\end{tabular}

The negative values of $\Delta \mathrm{G}_{\text {ads }}$ listed in Table 2 indicate the spontaneous adsorption of the additives molecules on the steel surface. The values of free energy $\Delta G$ less than $-40 \mathrm{KJ} / \mathrm{mol}$ indicates that such inhibitors are physically adsorbed on the metal surface ( Toliwal et al., 2010). However, in this present case the $\Delta \mathrm{G}$ values increased with increase in temperature reaching a maximum of $-43.40 \mathrm{KJ} / \mathrm{mol}$ at $323 \mathrm{~K}$; this tends to suggest a combination of physical and chemical adsorption. However, which predominates over the other is detected from the temperature studies, which in this case favours chemical adsorption. This means that a covalent type of bonding involving electron transfer from the inhibitor to the metal surface is assumed to have occurred ( Athareh, et al., 2004).

$\Delta \mathrm{G}=-2.303 \mathrm{RT} \log (55.5 \mathrm{~K})(4) \mathrm{K}=\theta / \mathrm{C}[1-\theta]$ Where $\mathrm{C}=$ concentration of the inhibitor. The percentage inhibition efficiency of the inhibitor from hydrogen gas evolution experiment can be calculated using

$\%$ inhibitor efficiency $=\frac{V_{b}-V_{i}}{V b} \times 100 \%$

Where $\mathrm{V}_{\mathrm{b}}$ and $\mathrm{V}_{\mathrm{i}}$ are the volumes of hydrogen evolved from gasometric method without and with inhibitor respectively at 30 minutes. The per cent inhibition efficiency results obtained from the gasometric method agrees with that of the weight loss as shown in Table 3.

Table 3: Comparison of percentage inhibition efficiency by weight loss and hydrogen gas evolution technique for mild steel corrosion in $2.0 \mathrm{M} \mathrm{H}_{2} \mathrm{SO}_{4}$ containing SBDAB at $303 \mathrm{~K}$

\begin{tabular}{lll}
\hline $\begin{array}{l}\text { Inhibition } \\
\text { Concentration(M) }\end{array}$ & \multicolumn{2}{l}{ Percentage inhibition efficiency \% } \\
\cline { 2 - 3 } & \multicolumn{2}{l}{$\begin{array}{l}\text { Height loss } \\
\text { method }\end{array}$} \\
\hline 0.000001 & 8.63 & 9.09 \\
0.00001 & 19.30 & 18.53 \\
0.0001 & 20.73 & 20.63 \\
0.001 & 32.92 & 32.52 \\
& &
\end{tabular}

Table 4: Kinetic data for mild steel corrosion in $2 \mathrm{M} \mathrm{H}_{2} \mathrm{SO}_{4}$ containing SBDAB from weight loss measurement.

\begin{tabular}{|c|c|c|c|c|c|c|c|c|c|c|}
\hline \multirow[t]{2}{*}{$\begin{array}{l}\text { inhibitor } \\
\text { Conc. (M) }\end{array}$} & \multicolumn{2}{|c|}{$\begin{array}{l}\text { Rate constant }(\mathrm{K}) \\
10^{2}\end{array}$} & \multicolumn{3}{|c|}{$\begin{array}{l}\text { Half life }\left(\mathrm{t}_{1 / 2}\right)(\mathrm{min}) \mathrm{x} \\
\left(\mathrm{KJmol}^{-1}\right)\end{array}$} & \multicolumn{2}{|c|}{$\begin{array}{r}\text { Activation energy } \\
\text { activation }\end{array}$} & \multicolumn{3}{|c|}{$\begin{array}{c}\text { Average }\left(\mathrm{min}^{-1}\right) \times 10^{-3} \\
\text { energy }\end{array}$} \\
\hline & $303 \mathrm{~K}$ & $313 \mathrm{~K}$ & $323 \mathrm{~K}$ & $303 \mathrm{~K}$ & $313 \mathrm{~K}$ & $323 \mathrm{~K}$ & $303-313 K$ & $\begin{array}{c}313- \\
323 \mathrm{~K} \\
\end{array}$ & $\begin{array}{r}303- \\
313 \mathrm{~K} \\
\end{array}$ & $\begin{array}{r}313- \\
323 \mathrm{~K}\end{array}$ \\
\hline $1.0 \times 10^{-6}$ & 4.25 & 5.09 & 5.18 & 1.63 & 1.36 & 1.34 & 13.63 & 1.47 & 8.79 & 2.92 \\
\hline $1.0 \times 10^{-5}$ & 4.17 & 4.75 & 5.02 & 1.66 & 1.46 & 1.38 & 9.84 & 4.65 & & \\
\hline $1.0 \times 10^{-4}$ & 4.09 & 4.42 & 4.51 & 1.69 & 1.57 & 1.54 & 5.87 & 1.69 & & \\
\hline $1.0 \times 10^{-3}$ & 3.62 & 4.24 & 4.36 & 1.91 & 1.63 & 1.59 & 11.95 & 2.35 & & \\
\hline $1.0 \times 10^{-2}$ & 3.38 & 3.50 & 3.69 & 2.05 & 1.98 & 1.88 & 2.64 & 4.44 & & \\
\hline
\end{tabular}

The rate constants and the half life $\left(\mathrm{t}_{1 / 2}\right)$ for the corrosion of steel at the various studied temperatures decreased from $303 \mathrm{~K}$ to $323 \mathrm{~K}$ and increased with increase in concentrations (Table 4); these confirm the inhibition of steel 
corrosion in $2.0 \mathrm{M} \mathrm{H}_{2} \mathrm{SO}_{4}$ by the inhibitor. The average activation energy is $8.79 \mathrm{KJmol}^{-1}$ and $2.92 \mathrm{KJmol}^{-1}$ for 303-313 K and 313-323 K respectively.

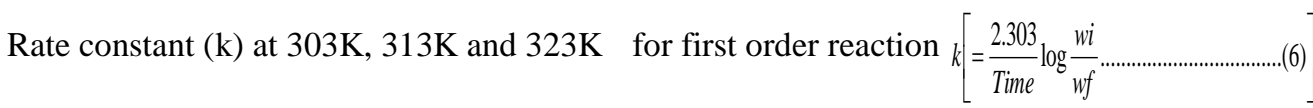

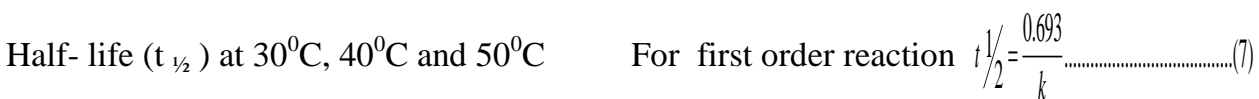

Activation energy $\left(\mathrm{K} \mathrm{Jmol}^{-1}\right) \quad E a=\frac{2.303 R T_{1} T_{2}\left(\log K_{2} / K_{1}\right)}{T_{2}-T_{1}}=\frac{\mathrm{Jmol}^{-1}}{1000}=\mathrm{KJmol}^{-1}$

Where $\mathrm{R}=$ is the gas constant in Joule $(\mathrm{J}) \quad \mathrm{T}=$ Absolute temperature in Kelvin $\mathrm{R}=8.314 \mathrm{Jmol}^{-1} \mathrm{~K}^{-1}$ or $8.314 \times 10^{-3} \mathrm{KJmol}^{-1} \mathrm{~K}^{-1} \mathrm{~K}_{1}$ and $\mathrm{K}_{2}$ are rate constants at $\mathrm{T}_{1}$ $(303 \mathrm{~K})$ and $\mathrm{T}_{2}(313 \mathrm{~K})$ respectively or $\mathrm{T}_{1}(313 \mathrm{~K})$ and $\mathrm{T}_{2}(323 \mathrm{~K})$.

Table 5: Surface coverage $(\theta)$ and corrosion rate for the inhibition of mild steel corrosion by SBDAB in $2.0 \mathrm{M}$ $\mathrm{H}_{2} \mathrm{SO}_{4}$ solution at different temperatures.

\begin{tabular}{llllllllll}
\hline Conc $(\mathrm{M})$ & \multicolumn{3}{c}{ Surface Coverage $\theta$} & \multicolumn{3}{c}{ Corrosion rate (mdd) mgdm } & \multicolumn{3}{c}{ Corrosion rate (mm/year) or mm per year } \\
& \multicolumn{3}{c}{ day $^{-1} \times 10^{3}$} & & & & $323 \mathrm{k}$ \\
\hline 0.000001 & 0.09 & 0.19 & 0.25 & 3.23 & 3.38 & 3.58 & 22.01 & 25.89 & 26.67 \\
0.00001 & 0.20 & 0.26 & 0.28 & 2.83 & 3.10 & 3.44 & 21.40 & 23.94 & 25.59 \\
0.0001 & 0.21 & 0.31 & 0.33 & 2.81 & 2.90 & 3.20 & 21.38 & 22.02 & 22.14 \\
0.001 & 0.34 & 0.36 & 0.39 & 2.36 & 2.67 & 2.91 & 18.22 & 20.92 & 21.66 \\
0.01 & 0.36 & 0.38 & 0.40 & 2.28 & 2.58 & 2.87 & 16.80 & 16.81 & 17.86 \\
\hline
\end{tabular}

The surface coverage $\theta$ increased with concentrations decreased with increase in concentration of the of the additives at the various temperatures which additives at the studied temperatures which supports a means that more of the inhibitors adsorbed on the chemisorption reaction mechanism.

steel surface (Table 5). Also the rate of corrosion

Table 6: Heat of adsorption $\Delta \mathrm{H}_{\text {ads }}$ and Entropy of adsorption $\Delta \mathrm{S}_{\text {ads }}$ for the inhibition of corrosion of mild steel by SBDAB at different concentrations in $2.0 \mathrm{M} \mathrm{H}_{2} \mathrm{SO}_{4}$ solutions at $303 \mathrm{~K}$

\begin{tabular}{lll}
\hline Concentration $(\mathrm{M})$ & Heat of adsorption $(\mathrm{KJ} / \mathrm{mol})$ & $\begin{array}{l}\text { Entropy of adsorption } \\
(\mathrm{J} / \mathrm{mol} / \mathrm{K})\end{array}$ \\
\hline 0.000001 & 11.11 & 148.15 \\
0.00001 & 7.32 & 125.31 \\
0.0001 & 3.35 & 93.66 \\
0.001 & 9.43 & 101.85 \\
0.01 & 10.12 & 53.04 \\
\hline
\end{tabular}

The positive values of $\Delta \mathrm{H}_{\mathrm{ads}}$ and $\Delta \mathrm{S}_{\mathrm{ads}}$ (Table 6) may likely be as a result of possible replacement of water molecules by the inhibitor during adsorption of the additives on steel surface.

$\Delta \mathrm{G}_{\mathrm{ads}}=\Delta \mathrm{H}_{\mathrm{ads}}-\mathrm{T} \Delta \mathrm{S}_{\mathrm{ads}}(9)$

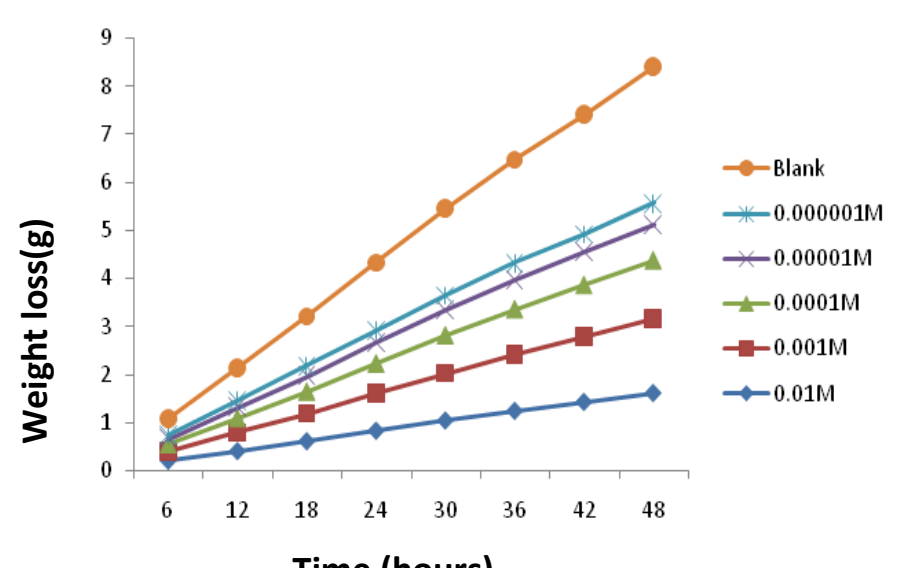

Fig 1 : Variation of Weight loss(g) with time(hours) for the corrosion of mild steel coupons in $2.0 \mathrm{M} \mathrm{H}_{2} \mathrm{SO}_{4}$ solution containing different concentrations of SBDAB at $303 \mathrm{~K}$

Weight loss decreased with increase in concentration of the inhibitor (Figure 1), this shows that the inhibitor molecules formed more monolayer on the surface of the steel thereby reducing the corrosion. 


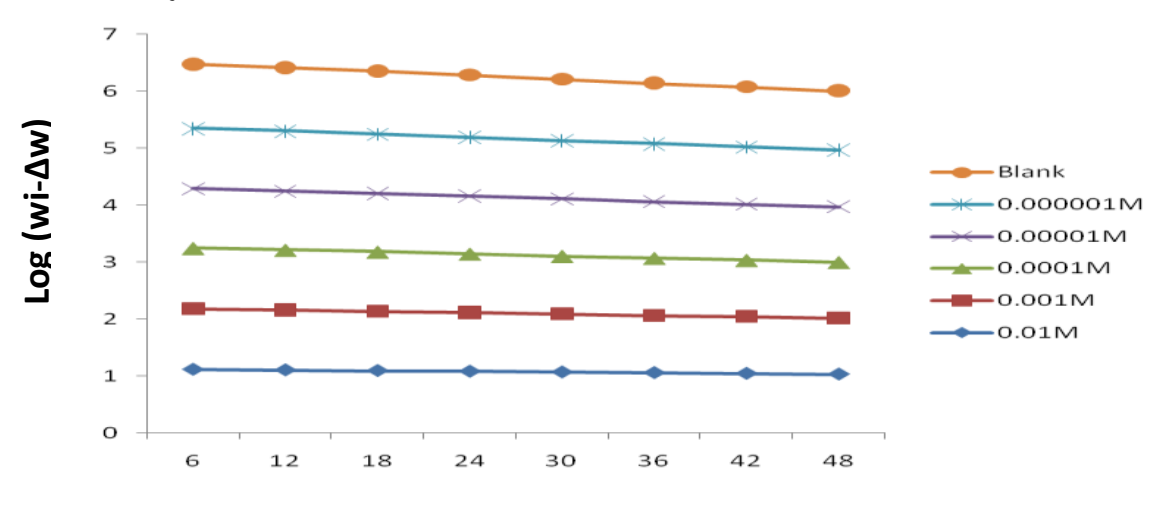

Fig 2: Variation of $\log \left(\right.$ wi- $\Delta \mathrm{w}$ ) with time (hours) for mild steel coupon dissolution in $2.0 \mathrm{M} \mathrm{H}_{2} \mathrm{SO}_{4}$ at different concentrations of SBDAB at 303K The plots of $\log ($ wi $-\Delta \mathrm{w}$ ) against time (Figure 2) are linear, these confirm a first order rate reaction kinetics for mild steel corrosion in $\mathrm{H}_{2} \mathrm{SO}_{4}$ solutions at the studied temperatures.

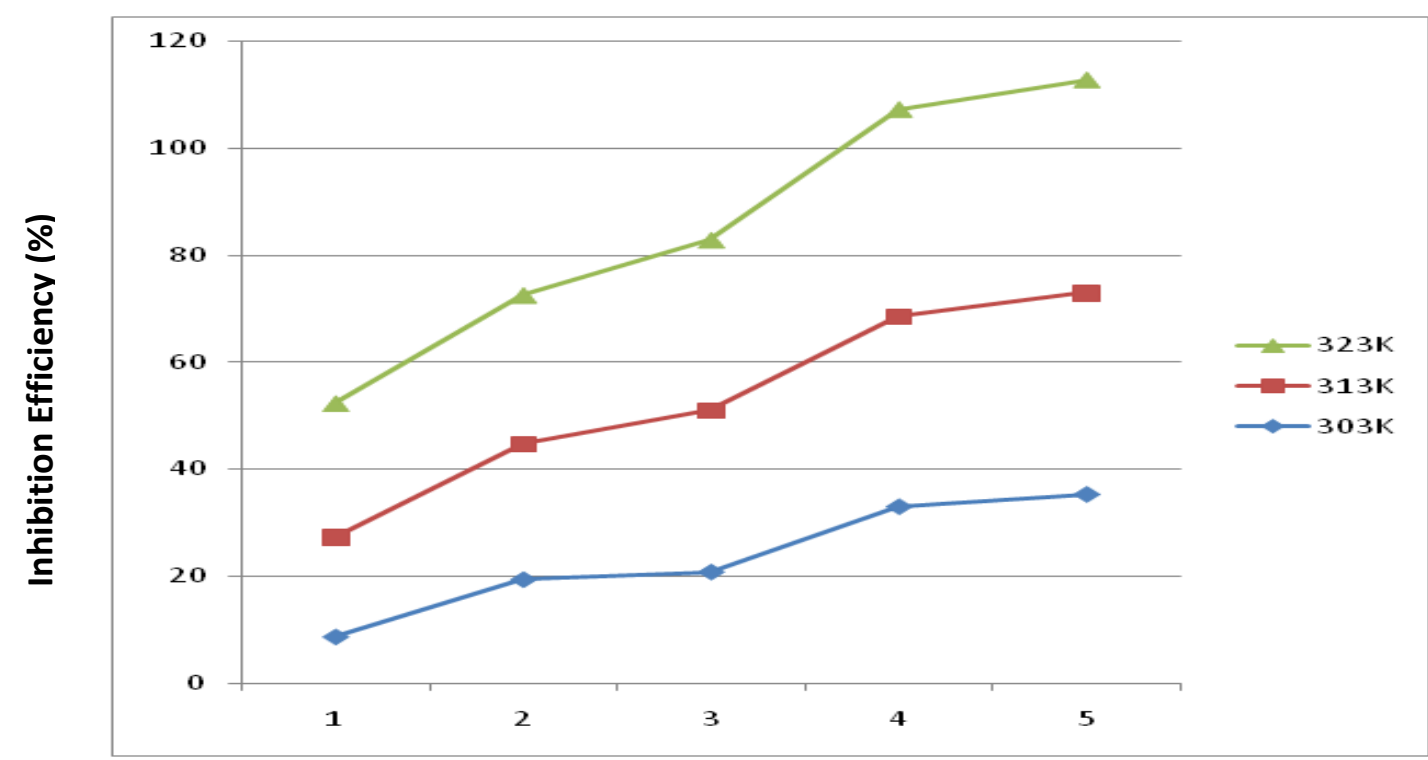

Concentration $(\mathrm{M})$

Fig 3: Variation of Inhibitor Efficiency with inhibitor concentration (M) for the corrosion of mild steel coupons in $2.0 \mathrm{M} \mathrm{H}_{2} \mathrm{SO}_{4}$ solution containing $\mathrm{SBDAB}$ at different temperatures.

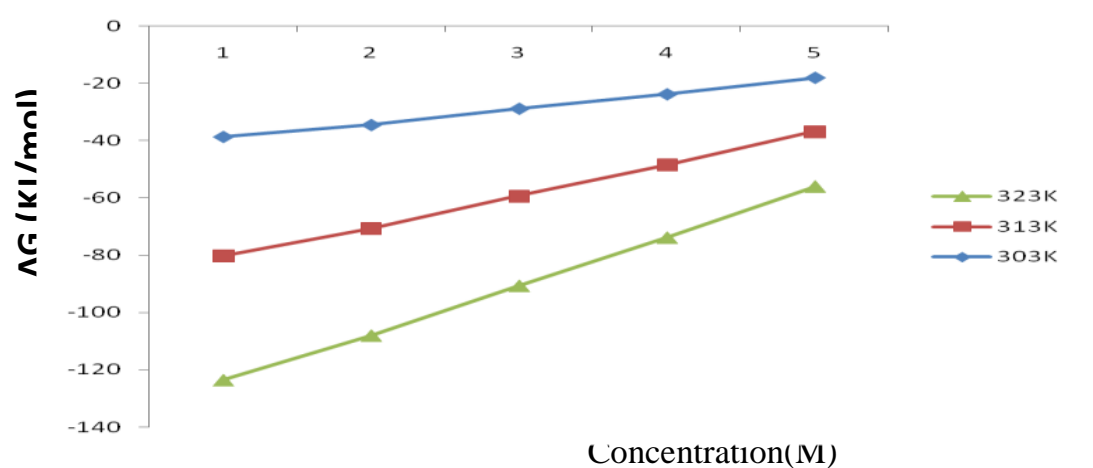

Fig 4: Variation of Free energy of adsorption $\triangle \mathrm{Gads}$ with temperature at different concentrations for SBDAB the inhibition of mild steel corrosion in $2.0 \mathrm{M} \mathrm{H}_{2} \mathrm{SO}_{4}$ solution. 


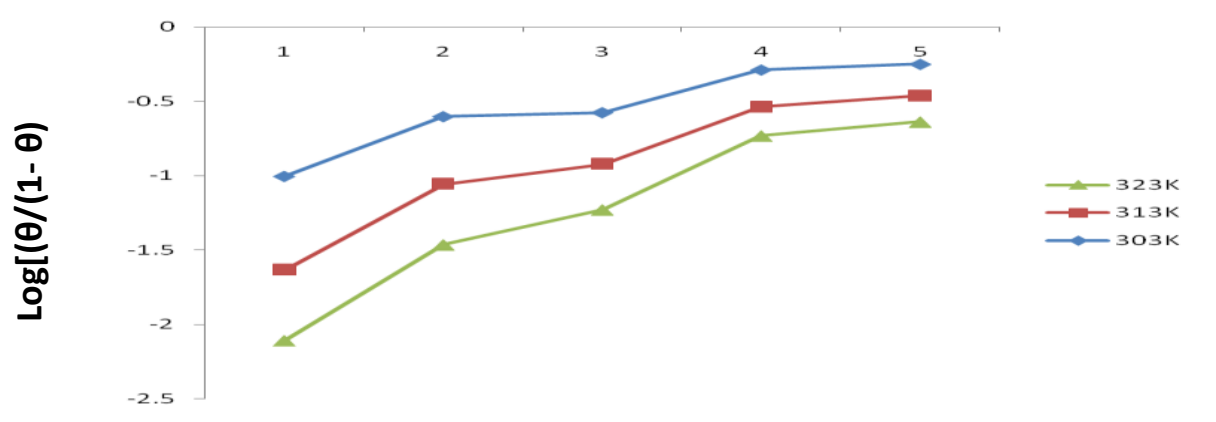

$\log C$

Fig 5 : Langmuir adsorption isotherm( plotted as $\log [\theta /(1-\theta)])$ versus $\log C$ for the inhibition of mild steel corrosion in $2.0 \mathrm{M} \mathrm{H}_{2} \mathrm{SO}_{4}$ solution by $\mathrm{SBDAB}$.

Figure 5 plot is linear but the gradient is not equal to unity. The deviation may be due to the fact that adsorbed species interact with each other on the metallic surface, Upadhyay and Mathur, (2007).

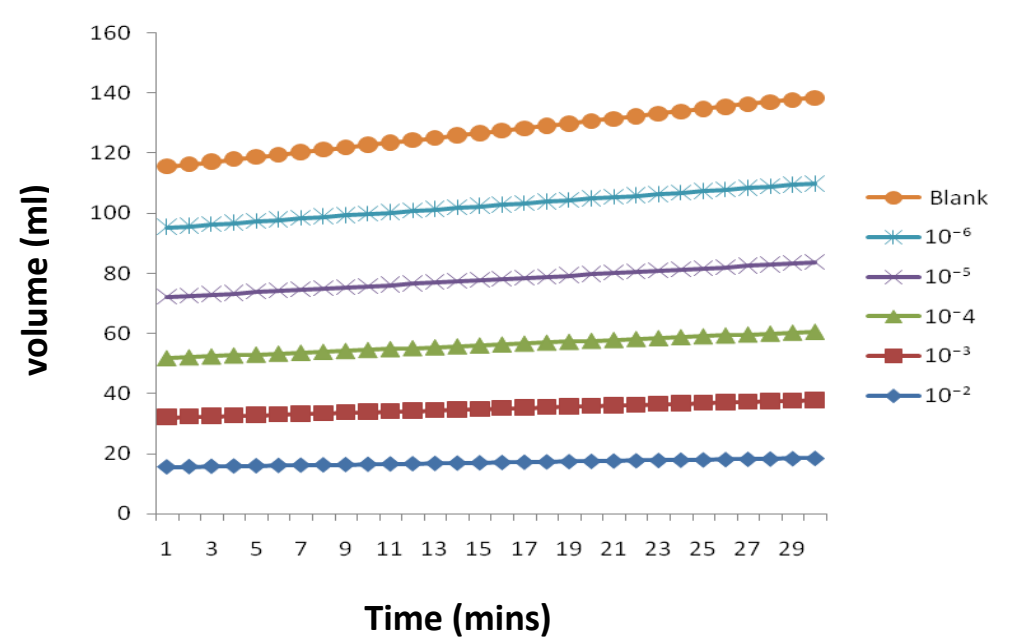

Fig 6 : Variation of Volume of hydrogen gas evolved with time ( minutes ) for the inhibition of mild steel corrosion in $8 \mathrm{M} \mathrm{H}_{2} \mathrm{SO}_{4}$ solution by $\mathrm{SBDAB}$ at $303 \mathrm{~K}$

Bukhari, HI (2002). Preparation, characterization and

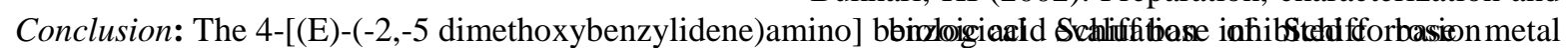
of steel in $2.0 \mathrm{M} \mathrm{H}_{2} \mathrm{SO}_{4}$. The inhibition efficiency increased with increase in temperature which suggests a chemisorption reaction mechanism. The inhibition efficiency increased with increase in concentration.

\section{REFERENCES}

ASTM (1990). Standard practice for laboratory immersion corrosion testing of metals, vol G 31 -72, P.401

Athareh, D; Iran, S; Fatemeh, B (2004). Corrosion inhibitory effects of a new synthetic symmetrical Schiff- base on carbon steel in acid media. Anti- corrosion methods and materials 51(4):266-271 complexes of some drug substances. A Ph.D Thesis, Bahauddin Zakariya University, Multan, Pakistan.

Chitra, S; Parameswari, K; Selvaraj, A (2010). Dianiline Schiff bases as inhibitors of mild steel corrosion in acid media. Int. J. Electrochem. Sci., 5: 1675 - 1697.

Cotton, FA; Wilkinson, G; Gaus, PL (1987). Basic inorganic chemistry. $2^{\text {nd }}$ ed Canada, John Wiley and sons.

Echem, OG; Oforka, NC; James, A0 (2013). Microwave assisted synthesis, characterization and anti-bacterial activity of Schiff base derived from 3-nitrobenzaldehyde and 2-aminophenol; 
3-nitrobenzaldehyde and 4-aminobenzoic acid. International Journal of research and advancement in bioscience, 3(1) : 58 - 67

El-hassy, NA (2004). Synthesis and investigation of tridentate Schiff base chelates. M.Sc. Thesis, Benghazi: Garyounis University.

Erma, SBMI (2010). Non-symmetrical Schiff Bases as corrosion inhibitors of mild steel in acidic solution. An unpublished Bachelor of Science degree project report, Universiti Teknologi MARA

Jezowska, B; Lisowski, J; Chemielewski, P (1988). Synthesis and spectroscopic studies of Schiff base complexes, Polyhedron 7(5):337-340.

Jones Maithard Jr (2000). Organic chemistry. W.W.Worton \& company, inc.pp 728-729. Journal of Applied Electrochemistry, 40(7): 134-136.

Mohamed ,QM (2011).Synthesis and characterization of new Schiff bases and evaluation as corrosion inhibitors. Journal of Basrah Researches (science) 37(4): 116-130.

Mounika, K; Anupama, B; Pragathi, J; Gyanakumari, C (2010). Synthesis, characterization and biological activity of a schiff base derived from 3-ethoxy salicylaldehyde and 2-aminobenzoic acid and its transition metal complexes. J. Sci. Res. 2(3):513

Pavia, DL; Lampman, GM; Kriz, GS (2001). Introduction to spectroscopy: A guide for students of organic chemistry, Washington, Thomason learning Inc pp386.

Sastri,VS (1998).Corrosion inhibitor, 373 ,new York, Wiley pp39-40

Sethi, S; Chaturvedi, A; Upadhay, RK; Mathur, SP (2007). Corrosion inhibitory effect of some Schiff's bases on mild steel in acid media. Journal of Chilean chemical society 52(3) :1206-1213

Singh, B; Srivastav, AK; Preet, S (1994). Template synthesis and characterization of some bivalent $3 \mathrm{~d}$ metal complexes of acetylacetone bis (20thenoylhydrazone). Synth. React. Inorg. Metorg. Chem., 24 (4): 631-645.

Toliwal, SD; Kalpesh, J; Pavagahh, I (2010). Inhibition of corrosion of mild steel INHCL solutions by Schiff base derived from non traditional oils, Journal of Applied chemical Research12:24 -36.

Zumdahl, SS (1986). Chemistry. Carada, D.C health and company pp 737 . 